\title{
Doing research in social work and social care: The journey from student to practitioner researcher
}

\author{
Catherine Flynn and Fiona McDermott, 2017 \\ Sage, London \\ ISBN 101473906628, pp. 240, paperback, NZD57.00
}

$\mathrm{S}$ ocial work and care settings increasingly call for the training and development of practitioner researchers as evidence (i.e., data gathered and analysed through research processes) is required to inform best practice interventions (ANZASW, 2013; Beddoe, Yates, Fouché, \& Harington, 2010; SWRB, 2016). Significant repeat references within the literature to the ambivalent relationship social work practitioners and students have in relation to learning about, doing, and making use of research exist (Chakradhar, 2018; Dodd \& Epstein, 2012; Epstein, 1987; Gray, Sharland, Heinsch, \& Schubert, 2015). Unfortunately, students struggle with the new, often challenging, language of research as well as understanding how it might fit into their future practice (Cameron \& Este, 2008; Jones \& Sherr, 2014; Unrau \& Grinnell, 2005). Several texts have been written that skilfully unpack the complexities of research concepts (Bryman, 2016; De Vos, Delport, Fouché, \& Strydom, 2011; Neuman \& Robson, 2014; Rubin \& Babbie, 2014)). However, for the novice researcher, these resources are not always accessible due to the density of content and use of technical language regarding the level of foundational research knowledge they may possess.

As a lecturer in the School of Counselling, Human Services and Social Work at the University of Auckland, in Aotearoa New Zealand, I can confidently remark that research-averse attitudes are representative of social work students enrolling in a research course for the first time. I refer to these students as being research-allergic, as my experience teaching research courses confirms what the literature says about students being research-phobic. Flynn and McDermott promise tools to build confidence in relation to both comprehending and using research for evidence-based practice (EBP). In trialling the incorporation of its ideas, their book proved to be a useful resource for many of the once apprehensive, researchallergic, social work research students.

The authors of Doing Research in Social Work and Social Care acknowledge the tension between research and professional social work and care practice contexts early on in the book. However, the book is not another academic piece focused on 'why research is necessary to social work and social care students and practitioners' (although this becomes increasingly evident through its engaging real-world examples). Instead, the text serves as an introductory 'how-to guide' for doing research where the authors place a strong emphasis on producing rather than consuming research. As such, the book is positioned as a tool to manoeuvre the uneasiness with which both students and practitioners approach incorporating research into practice.

The authors segment this book into three parts in order to purposefully hold the reader's hand through each step of the research process: 1) preparing for research; 2) doing research; and 3) making use of research. Part one is spread across four chapters. The layout assuages reader 
anxieties about the intimidating nature of research through articulately describing the essential building blocks of research knowledge. Combined, these four chapters allow the reader to understand the answers to several questions: Why do research in the professional practice context? How does research develop? Why is what you do in research and how you do it (i.e., ethics) important? And finally, How are research questions formulated? Part one leaves the reader less intimated and more excited to begin doing research.

In Part two, the reader finds themselves considering how their study might take shape. Multiple elements of research design are traversed (e.g., study and aims, sampling, data collection methods, and data analysis). Part two finishes with the inclusion of 'the toolkit'. This is an attractive element for lecturers, first-time research students or practitioner researchers. The authors deliver short, smart resources for kick-starting two different aspects of research: 1) a template for organising a literature review; and, 2) a research proposal formatting guide. While beneficial, the toolkit aspect of the book left me wanting more exercises and 'getstarted' activities or tools I could share with my students to support their independent research. Part three focuses on making meaning of both qualitative and quantitative data-or how to put the knowledge gleaned from research to use. The authors provide synopses of various strategies for analysis and creative dissemination. The take-away message of this section reminds the reader that 'context matters' in all aspects of conceptualising research.

There are several strengths threaded throughout the text. In particular, Flynn and McDermott use student-friendly, engaging language. This worked well to simplify complex research concepts into useable ideas for the novice social work researcher. At times, further details on a specific aspects of research were required due to the nature and scope of the course I was teaching. However, Flynn and McDermott's book provided the ideal foundation to begin consuming thicker descriptions of research located in enduring research texts such as Bryman (2016), Rubin \& Babbie (2014), or Research at the Grassroots by De Vos and colleagues (2011). The 'key take-home messages' section at the end of each chapter often utilised powerful imagery to elicit reflection on the research project as a whole, rather than its individual parts. These sections also served as snippets to guide both effective and ethical research practice.

Why should Flynn and McDermott's text be the staple resource for introductory social work and social care research papers? After personally experimenting with much of the content in an undergraduate Bachelor of Social Work (BSW) applied social research paper with a group of 39 research-allergic students, the majority reflected that the book's ideas integrated into weekly lectures and tutorials made the idea of conducting research-in-practice more tangible. For some, the content exported from the text enabled students to make sense of previous BSW coursework ideas and experiences they encountered during third-year practicum placements. This was especially true of the Chapter Five content related to research design, where students reflected on how they might develop a research project relating specifically to their practicum organisations. It is indicative from overall course feedback in my undergraduate courses that the need to and value of locating research in social work practice settings was recognised through incorporation of content from this book.

For students, the material is easily digestible which is necessary for those first encountering the language of research. This book achieves relevance and accessibility through the inclusion of case studies, researcher experience comments and insights (referred to as the chorus), as well as accessible figures. These key components of foundational learning for research-inpractice were valuably tailored to the book's two main audiences and skilfully woven throughout each chapter. 
For teaching purposes, the objectives set out at the beginning of each chapter were helpful in formulating lecture learning outcomes and establishing a teaching direction. The reflection questions and case studies were easily adaptable into engaging classroom activities - making pivotal concepts memorable. In addition, sharing the authors' conceptualisation of 'research as journey', was a useful metaphor to first-time research students who achieved a sense of comfort in the fact that they were beginning their own journeys into application of EBP. For current practitioners in the social work or care settings wanting to dip their toes in to test the metaphorical research waters, this book is a great first step.

The authors will entice all who read the book to take the plunge into the wonderful world of practice-based research! Just as it is important to have a greater understanding of the allergic triggers that might cause a flareup, I now encourage my students to identify their research-related "trigger words" (e.g., epistemology, ontology, paradigm, and rigour) early on in the semester. Chapters within Flynn and McDermott's text continue to be a good resource where I refer students to explore the concepts they identify as trigger words in digestible formats. It is with a strong recommendation I suggest adopting the use of this book in BSW introductory research papers. I look forward to increasing integration of this text into the social work research papers that I teach.

\section{References}

Aotearoa New Zealand Association of Social Workers (ANZASW). (2013). Code of ethics. Christchurch, New Zealand: Author.

Beddoe, L., Yates, D., Fouché, C. B., \& Harington, P. (2010). Practitioner research made easier: A report on the GRIP project. Aotearoa New Zealand Social Work Review, 22(2), 22-36.

Bryman, A. (2016). Social research methods. Oxford, UK: Oxford University Press.

Cameron, P. J., \& Este, D. C. (2008). Engaging students in social work research education. Social Work Education, 27(4), 390-406.
Chakradhar, K. (2018). Forging and sustaining researchminded professionals: Teaching undergraduate research through student-community partnerships. Social Work Education, 37(4), 428-441.

De Vos, A. S., Delport, C. S. L., Fouché, C. B., \& Strydom, H. (2011). Research at grass roots: A primer for the social science and human professions. Pretoria, South Africa: Van Schaik Publishers.

Dodd, S. J., \& Epstein, I. (2012). Practice-based research in social work: A guide for reluctant researchers. London, UK: Routledge.

Epstein, I. (1987). Pedagogy of the perturbed: Teaching research to the reluctants. Journal of Teaching in Social Work, 1(1), 71-89. doi:10.1300/J067v01n01_06

Gray, M., Sharland, E., Heinsch, M., \& Schubert, L. (2015). Connecting research to action: Perspectives on research utilisation. British Journal of Social Work, 45(7), 1952-1967. doi:10.1093/bjsw/bcu089

Jones, J. M., \& Sherr, M. E. (2014). The role of relationships in connecting social work research and evidence-based practice. Journal of Evidence-Based Social Work, 11(1-2), 139-147.

Neuman, W. L., \& Robson, K. (2014). Basics of social research. Toronto, ONT: Pearson Canada

Rubin, A., \& Babbie, E. R. (2014). Research methods for social work (Eighth edition. ed.). Belmont, Calif.: Brooks/ Cole Cengage Learning

Social Workers Registration Board (SWRB). (2016). Code of conduct. Wellington, New Zealand: Author.

Unrau, Y. A., \& Grinnell, R. M., Jr. (2005). The impact of social work research courses on research self-efficacy for social work students. Social Work Education, 24(6), 639-651. 